\title{
PENGEMBANGAN DAN PELATIHAN PENGGUNAAN E-LEARNING PADA MTS MUHAMMADIYAH 3 AL-FURQON BANJARMASIN
}

\author{
Kun Nursyaiful Priyo Pamungkas ${ }^{1}$, Joni Riadi ${ }^{2}$, Ida Hastuti $^{3}$, Yoenie Indrasary ${ }^{4}$ \\ Politeknik Negeri Banjarmasin 1,2,3,4 \\ koen_pp@poliban.ac.id ${ }^{l}$ \\ joni_akademika@yahoo.com ${ }^{2}$ \\ dhapoliban@gmail.com ${ }^{3}$ \\ yoenie.indrasary@poliban.ac.id ${ }^{4}$
}

\begin{abstract}
This Service activity was held at MTS Muhammadiyah 3 Al-Furqon Banjarmasin. Based on a field survey, the MTS Muhammadiyah 3 Al-Furqon Banjarmasin for the process of teaching and learning activities fully uses manual methods and does not have school elearning. The full use of the manual method can be enhanced by the addition of elearning as a means of effective teaching and learning activities. E-learning is built to accommodate teachers in providing learning needs to students. Learning needs are like learning materials that can be accessed anytime and anywhere are efficient in storing teaching materials and tasks, and it is practical to use. The target to be achieved from this service activity that schools can have e-learning to accommodate teachers in learning needs management and facilitate teaching and learning activities between teachers and students. This service activity is expected to be useful for school residents to access teaching materials easily, efficiently and can be done whenever and wherever they are without knowing distance and time.
\end{abstract}

Keywords: e-learning, school, technology utilization

\begin{abstract}
ABSTRAK
Kegiatan Pengabdian Kepada Masyarakat ini dilaksanakan di MTS Muhammadiyah 3 AlFurqon Banjarmasin. Berdasarkan survey lapangan, di MTS Muhammadiyah 3 Al-Furqon Banjarmasin untuk proses kegiatan belajar mengajar sepenuhnya menggunakan metode manual dan belum memiliki e-learning sekolah. Pemanfaatan metode manual sepenuhnya tersebut dapat ditingkatkan dengan penambahan e-learning sebagai sarana kegiatan belajar mengajar yang efektif. E-learning yang dibangun guna mengakomodasi guru dalam memberikan kebutuhan belajar pada siswa. Kebutuhan belajar tersebut seperti bahan belajar yang dapat diakses kapan saja dan dimana saja, efisien dalam penyimpanan bahan ajar dan tugas, dan praktis pada penggunaannya. Target yang hendak dicapai dari kegiatan pengabdian kepada masyarakat ini adalah agar sekolah dapat memiliki $e$ learning sekolah untuk mengakomodasi guru dalam manajemen kebutuhan belajar dan mempermudah kegiatan belajar mengajar antara guru dan siswa. Kegiatan pengabdian masyarakat ini diharapkan bermanfaat guna warga sekolah dapat mengakses bahan ajar dengan mudah, efisien serta dapat dilakukan kapanpun dan dimanapun mereka berada tanpa mengenal jarak dan waktu.
\end{abstract}

Kata Kunci: e-learning, sekolah, pemanfaatan teknologi 


\section{PENDAHULUAN}

Perkembangan teknologi informasi memainkan peranan yang sangat penting dalam berbagai bidang, seperti industri, perdagangan, kesehatan, pendidikan dan sebagainya. Internet merupakan jaringan komputer global di seluruh dunia dan dapat diakses dimana saja dan kapanpun sebagai media komunikasi yang dapat memberikan berbagai informasi kepada publik. Suatu lembaga pendidikan pemerintah atau swasta dapat memberikan informasi atau ilmu dengan melalui bahan ajar kepada warga sekolah. Akses Bahan ajar yang didukung dengan teknologi dan internet terdapat pada e-learning sekolah.

Dalam dunia pendidikan, salah satu dari kegiatan belajar mengajar ialah penyampaian informasi. Penyampaian informasi yang menarik dapat membuat siswa untuk memahami pembelajaran. Kegiatan belajar mengajar pada MTS Muhammadiyah 3 Al-Furqon Banjarmasin sepenuhnya menggunakan metode manual, seperti penulisan pada papan tulis, pendalaman materi lewat buku dan pengumpulan tugas berupa kertas atau makalah. Kegiatan tersebut memiliki dampak seperti membuat siswa kurang efektif menyerap informasi pelajaran, meja kerja guru yang dipernuhi tugas-tugas dari muridnya dan ketahanan terhadap kerusakan pada bahan ajar atau tugas yang bersifat fisik.

Berdasarkan analisis situasi di atas, maka yang menjadi permasalahan mitra adalah bagaimana membangun e-learning sekolah. Adapun tujuan pada kegiatan ini adalah dapat menggunakan e-learning berbasis web sebagai media pembelajaran pada MTS Muhammadiyah 3 Al-furqon Banjarmasin. Sedangkan manfaat dari kegiatan ini yaitu e-learning menyimpan bahan ajar dari guru yang bersifat softcopy sebagai tindakan pengaman dari kehilangan data pada harddisk / laptop yang rusak, e-learning membantu guru melakukan penilaian terhadap siswa, warga sekolah dalam mengakses e-learning dapat dilakukan kapanpun dan dimanapun tanpa mengenal jarak dan waktu.

\section{METODE KEGIATAN}

Metode pelaksanaan dalam kegiatan pengabdian kepada masyarakat sub bidang Ipteks bagi Masyarakat adalah dalam bentuk konsultasi, difusi iptek dan pelatihan. Konsultasi digunakan untuk kegiatan-kegiatan yang di dalamnya persoalan atau kebutuhan dalam masyarakat diselesaikan melalui sinergisme dengan Perguruan Tinggi, Difusi Ipteks digunakan untuk kegiatan yang menghasilkan produk bagi konsumen dan Pelatihan digunakan untuk kegiatan yang melibatkan penyuluhan tentang substansi kegiatan yang disertai dengan demonstrasi atau percontohan untuk realisasinya. Untuk pembagian secara rinci pada metode pelaksanaannya terdapat pada Gambar 1. 


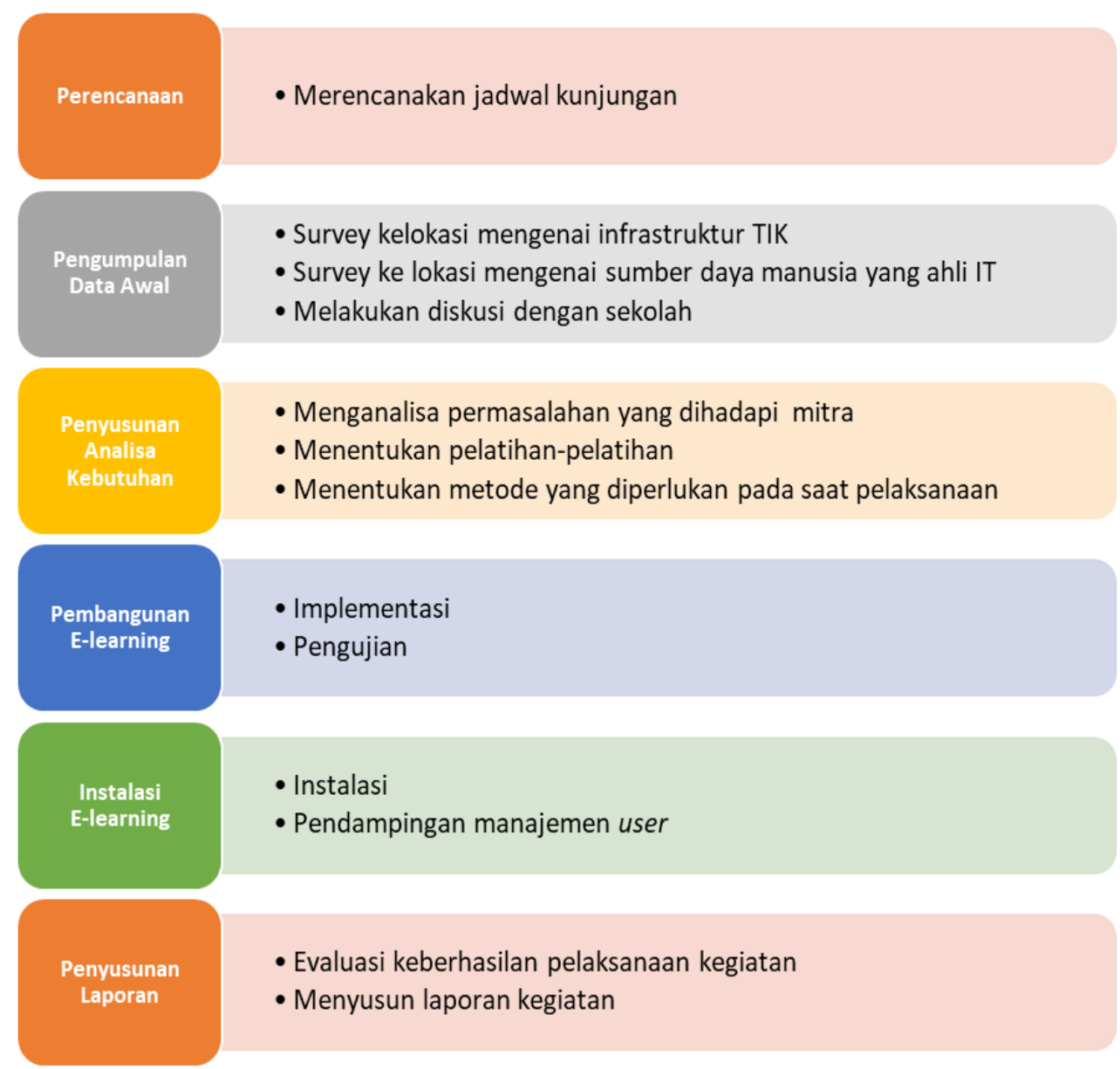

Gambar 1. Metode Pelaksanaan

Pada tahapan perencanaan, kegiatan pengabdian kepada masyarakat ini akan dilaksanakan pada jam kerja di MTS Muhammadiyah 3 Al-furqon Banjarmasin dengan mendapatkan ijin dari kepala sekolahnya terlebih dahulu. Pada tahapan pengumpulan data awal, melakukan diskusi dengan pihak sekolah terkait infrastruktur teknologi yang sudah ada dan sumber daya manusia yang ahli IT. Pada tahapan penyusunan analisa kebutuhan, melakukan analisa terkait permasalahan yang dihadapi dan menentukan pelatihan yang diperlukan. Pada tahapan pembangunan e-learning melakukan implementasi dan pengujian. Pada tahapan instalasi dengan melakukan instalasi e-learning di hosting dan pendampingan manajemen user. Dan terakhir adalah penyusunan laporan kegiatan.

Setelah selesai kegiatan pengabdian kepada masyarakat ini, program masih berlanjut pada pemantauan penggunaan e-learning. Apabila pihak sekolah menemukan masalah, para tim pelaksana kegiatan pengabdian kepada masyarakat siap untuk membantu selama dalam kurun waktu 1 tahun terhitung setelah pelatihan.

\section{HASIL DAN PEMBAHASAN}


Kegiatan pengabdian dilaksanakan pada hari sabtu, tanggal 15 September 2018, waktu 09.00 WITA di Ruang rapat MTS Muhammadiyah 3 Al-Furqon Banjarmasin. Peserta yang hadir merupakan guru berjumlah 28 orang, 5 orang pelaksana utama terdiri dari tim pengabdian dan mahasiswa, dan 7 orang pelaksana pembantu merupakan dosen dari program studi. Untuk pengaturan tempat terdapat pada Gambar 2.

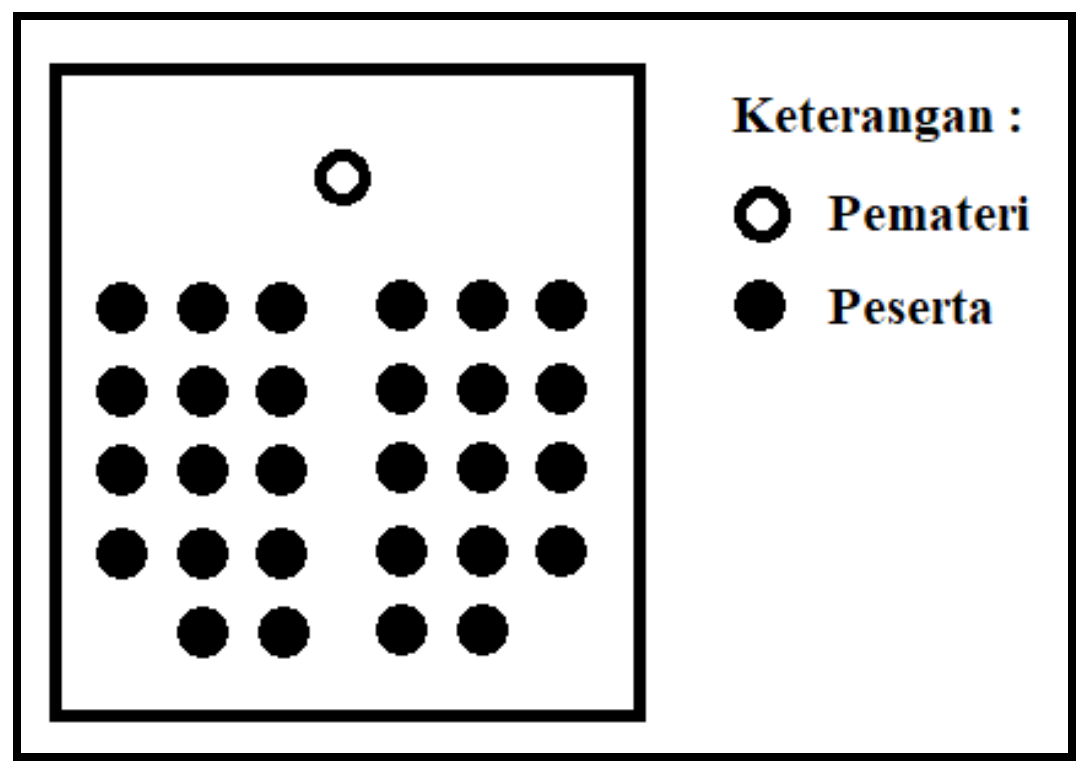

Gambar 2. Pengaturan Tempat

Luaran yang dicapai pada kegiatan ini adalah publikasi jurnal pengabdian dan e-learning sekolah MTS Muhammadiyah Al-furqon 3 Banjarmasin. Alamat website yang disepakati dengan pihak manajemen sekolah adalah www.mts_m3alfurqan.sch.id. E-learning dapat diakses dengan menggunakan aplikasi browser seperti google chrome, mozilla firefox, atau opera. E-learning pada kegiatan ini dipublikasi secara online, sehingga dapat diakses kapanpun dan dimanapun. Untuk menu utama yang disediakan adalah sistem login, manajemen user, manajemen kategori, manajemen mata pelajaran, dan manajemen nilai siswa. Pada Gambar 3 merupakan capaian peserta tentang pemahaman penggunaan e-learning. Pada gambar tersebut, peserta tidak memahami proses manajemen matapelajaran dan manajemen nilai. Hal tersebut dikarenakan peserta yang masih awam akan teknologi dan sulit memahami bisnis proses dari menu tersebut. 


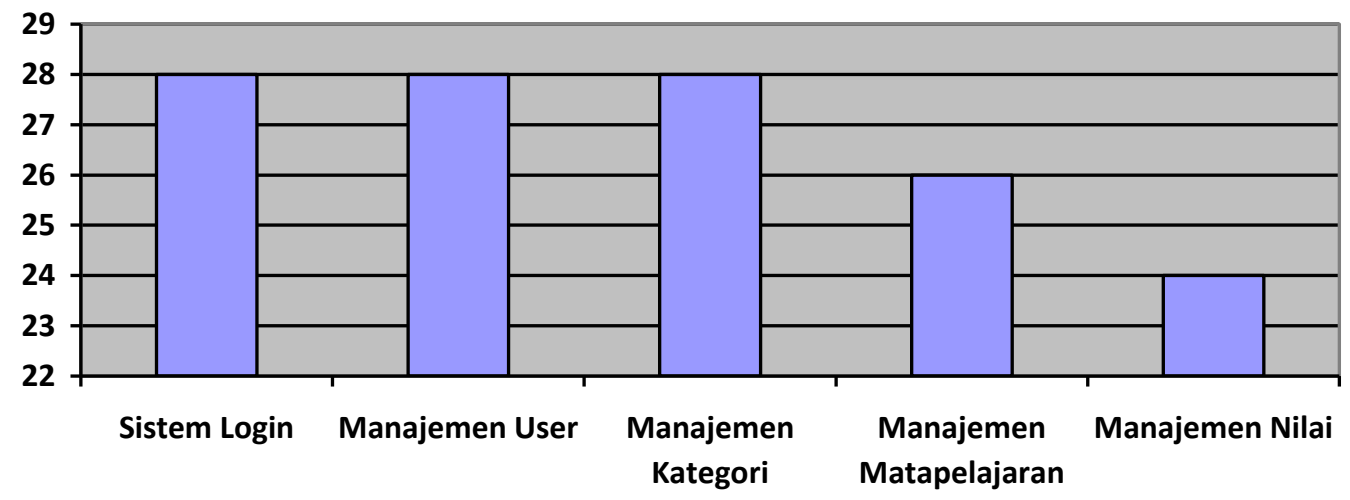

Gambar 3. Capaian Peserta tentang Pemahaman Penggunaan E-Learning

Dokumentasi kegiatan pengabdian meliputi pembukaan sebagaimana pada Gambar 4, pelaksanaan bimbingan / pelatihan pada Gambar 5, dan foto bersama pada Gambar 6. Keunggulan luaran pada kegiatan pengabdian ini adalah sistem informasi yang bersifat online, sehingga untuk pengaksesan dapat dilakukan dimanapun dan kapanpun. Kekurangan dari luaran ini adalah berbasis teknologi melalui komputer, sehingga peserta yang awam pada teknologi memiliki kesulitan dalam mengikuti pelatihannya sebagaimana pada Gambar 3. Tingkat kesulitan dalam kegiatan pengabdian ini adalah pemahaman peserta akan e-learning yang dibangun, dikarenakan e-learning merupakan sistem yang kompleks maka peserta harus mengenal dengan baik akan teknologi sebelumnya, untuk menutupi kelemahan tersebut, tim pengembang membuatkan modul e-learning sebagai pembelajaran dan konsultasi secara gratis via telepon.

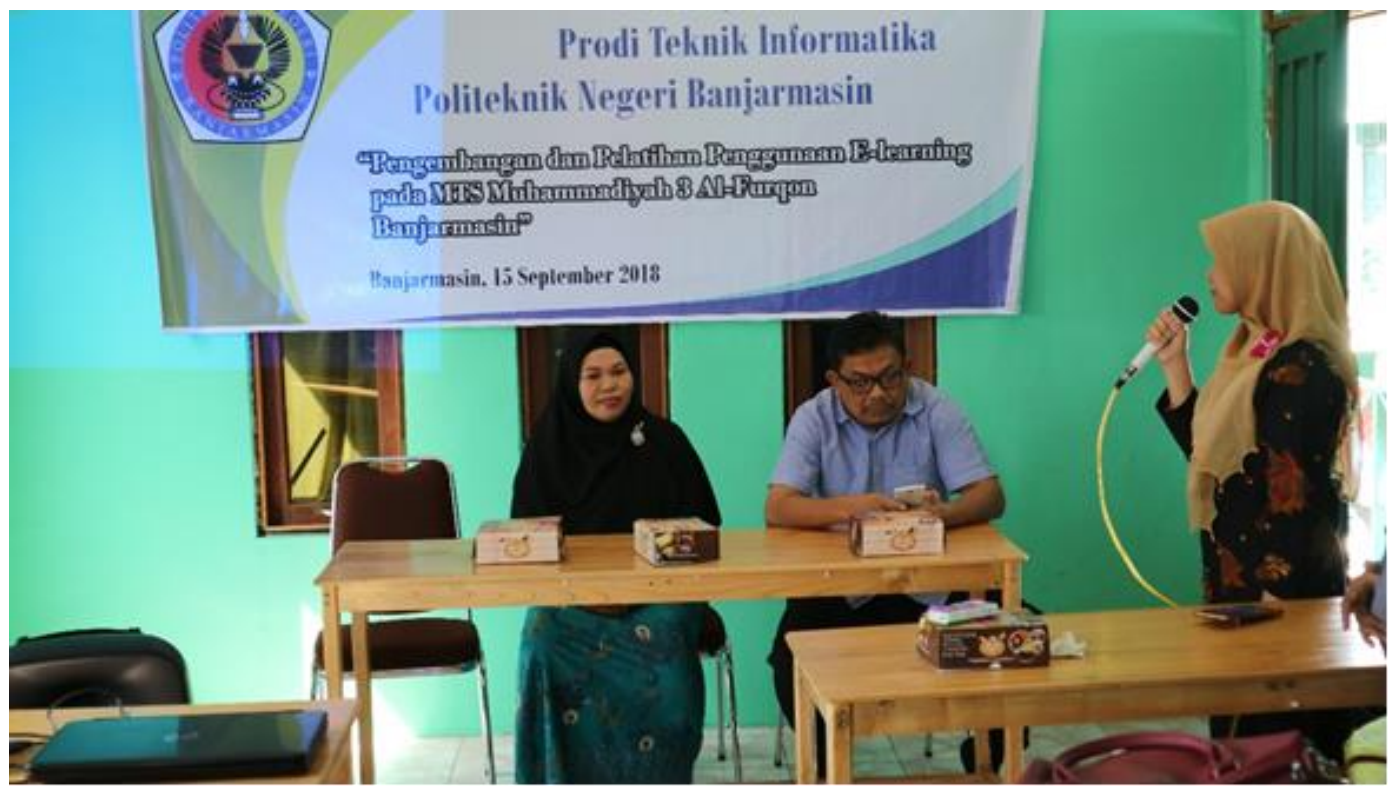

Gambar 4. Pembukaan 


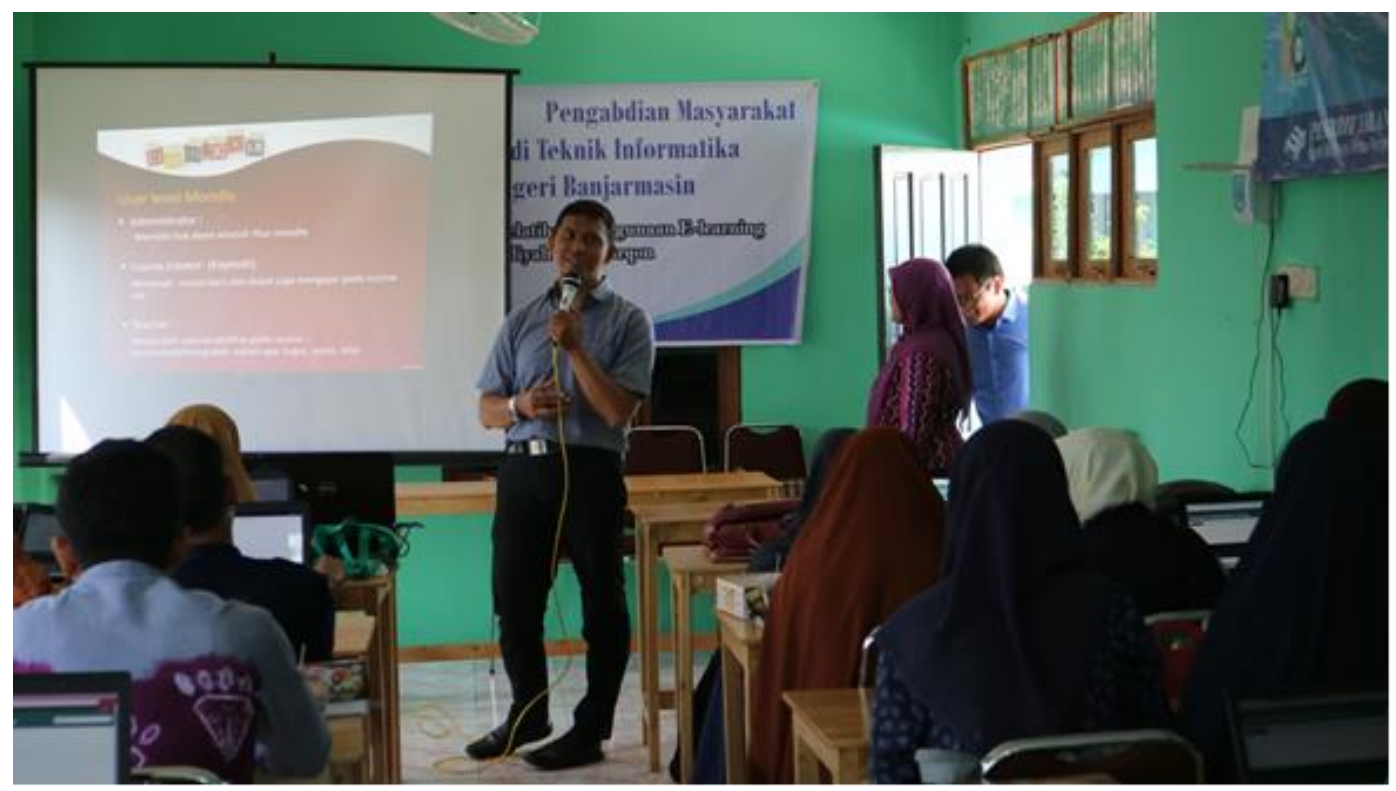

Gambar 5. Pelaksanaan Bimbingan / Pelatihan

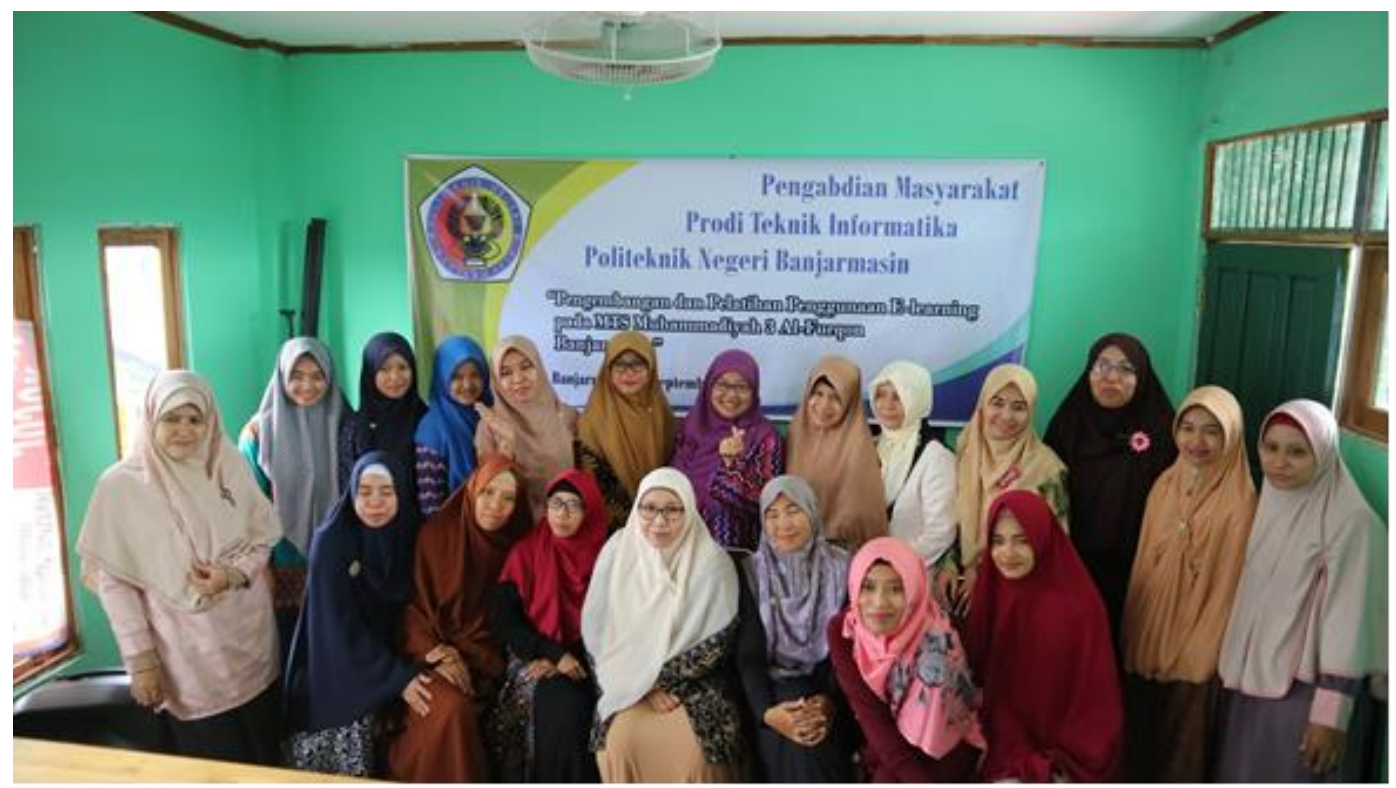

Gambar 6. Foto Bersama

\section{KESIMPULAN}

Kesimpulan melalui pembangunan dan pelatihan e-learning ini, maka akan sangat membantu sekali dalam penyampaian informasi proses belajar mengajar. Baik itu informasi teori dan ujian semester. Kegiatan pengabdian kepada masyarakat juga dapat berjalan dengan baik dengan mengikutsertakan peran mahasiswa sebagai pendamping peserta ketika proses pelatihan peserta. 
Saran yang dapat disampaikan ialah e-learning ini hendaknya bisa dipakai oleh admin yang telah ditunjuk oleh kepala sekolah secara berkelanjutan sehingga data dan informasi yang diberikan di dalam e-learning bersifat yang terbaru.

\section{UCAPAN TERIMA KASIH}

Kami ucapkan terimakasih banyak kepada Poliban melalui unit P3M yang telah membantu dalam pemberian dana hibah kegiatan pengabdian masyarakat.

\section{DAFTAR PUSTAKA}

Abdul Kadir, Pengenalan Sistem Informasi, Penerbit Andi Yogyakarta, Yogyakarta: 2002

Chandrawati, Rahayu. S., 2010, Pemanfaatan E-Learning dalam Pembelajaran, No.2, Vol.8, Jurnal Universitas Pertahanan.

Fathansyah, 1999, Basis Data, Informatika Bandung, Bandung.

Kurniawan, Yahya, 2004, Aplikasi Web Database dengan PHP dan MySQL, PT Elex Media Komputindo, Jakarta.

Nursalam dan Ferry Efendi, 2008, Pendidikan dalam Keperawatan, Jakarta:Salemba Medika

Purba S. D., Sopyan A., Hartono., 2006, Aktivitas Belajar Dan Penguasaan Materi Siswa dengan Pembelajaran Berbasis Portofolio pada Mata Pelajaran Sains Fisika SMP, Jurnal Pend. Fisika Indonesia, Vol.4, No.2 